\title{
Analisis Kesalahan Siswa dalam Menyelesaikan Permasalahan Perkalian Bilangan Bulat
}

\author{
Florida Moza \\ Fakultas Keguruan dan Ilmu Pendidikan, Universitas Sanata Dharma \\ Email: florida.moza@gmail.com
}

\begin{abstract}
Title (Analysis of Student Errors in Solving Integral Multiplication Problems). Integer multiplication is one of the main subjects taught in class VII. This study aims to describe the types of student errors about integer multiplication. This type of research used this research is descriptive qualitative research. The subjects of this study were students of class VII SMPK St. Paulus Karuni. The instrument in this study is a integer multiplication test item that has been designed according to the problems student normally work on, namely in working on the problem, it is made step by step that requires students to write their changes and their reason. The reason given was in the form of a contract and the theorems according to what they had learned. Data collection methods in the form of test result. Data analysis techniques used are (1) data reduction, (2) data display, and (3) conclusion drawing and verification. The result showed that students made several mistakes in solving problem about integer multiplication such as concept errors, syntax errors (writing errors), counting errors (semantic errors) and errors seeing operation marks.
\end{abstract}

Keywords: Qualitative Descriptive, Student Error, Integral Multiplication.

\begin{abstract}
Abstrak . Perkalian bilangan bulat merupakan salah satu materi pokok yang diajarkan di kelas VII. Penelitian ini bertujuan untuk mendeskripsikan jenis-jenis kesalahan siswa tentang perkalian bilangan bulat. Jenis penelitian yang digunakan dalam penelitian ini adalah penelitian deskriptif kualitatif. Subjek penelitian ini yaitu siswa kelas VII SMPK St. Paulus Karuni. Instrumen pada penelitian ini berupa soal tes perkalian bilangan bulat yang telah dirancang sesuai dengan soal yang biasa siswa kerjakan yaitu dalam pengerjaan soal tersebut dibuat langkah demi langkah yang membutuhkan siswa menuliskan pengubahannya beserta alasannya. Alasan yang diberikan adalah berupa kontrak dan teorema-teorema yang sesuai yang telah mereka pelajari. Metode pengumpulan data berupa hasil tes. Teknik analisis data yang digunakan yaitu (1) reduksi data (data reduction), (2) paparan data (data display), dan (3) penarikan kesimpulan dan verifikasi (conclusion drawing/verifying). Hasil penelitian menunjukkan bahwa siswa melakukan beberapa kesalahan dalam menyelesaikan permasalahan tentang perkalian bilangan bulat seperti kesalahan konsep, kesalahan sintaksis (kesalahan penulisan), kesalahan menghitung (Kesalahan semantik), dan kesalahan melihat tanda operasi.
\end{abstract}

Kata kunci: Deskriptif Kualitatif, Kesalahan Siswa, Perkalian Bilangan Bulat.

\section{PENDAHULUAN}

Matematika adalah ilmu tentang bilangan, hubungan antara bilangan dan prosedur operasional yang digunakan dalam penyelesaian masalah mengenai bilangan (Departemen Pendidikan Nasional : 2008). Menurut Ainurrohmah \& Mariana dalam Karlimah, dkk (2019), pemahaman konsep matematika merupakan bagian penting yang harus dipelajari oleh siswa karena sering dibutuhkan dan diimplementasikan pada aktivitas sehari-harinya, baik di sekolah, di rumah maupun di lingkungan masyarakat. Heather C. Hill dalam Karlimah, dkk (2019), menjelaskan dalam materi pelajaran matematika terkait pemahaman konsep yang harus dimiliki para siswa diantaranya adalah pemahaman operasi hitung. Bilangan bulat merupakan salah satu materi dalam matematika. Karso, dkk (2011), menjelaskan bilangan bulat adalah bilangan yang terdiri dari bilangan bulat positif, bilangan bulat negatif dan bilangan nol $(\ldots,-3,-2,-1,0,1,2,3, \ldots)$. Bilangan bulat merupakan materi yang sangat penting bagi siswa untuk dipelajari, karena kegunaannya dalam menyelesaikan berbagai masalah dalam kehidupan sehari-hari serta bahan prasyarat untuk mempelajari konsep-konsep lain, seperti koordinat Cartesian dan aljabar (Ate. 2016).

Menurut Kurikulum 2013, materi bilangan bulat diajarkan di kelas VII pada semester satu. Salah satu materi pokok yang diajarkan di kelas VII adalah Perkalian Bilangan Bulat. Perkalian Bilangan Bulat dapat diartikan sebagai penjumlahan berulang. Jadi untuk mencari hasil dari $a \times b$ sama halnya dengan menunjukkan penjumlahan $b+b+b$...sebanyak a kali (Gatot, dkk.2015).

Perkalian bilangan bulat merupakan materi pokok yang diajarkan sejak sekolah dasar dan diajarkan di SMP. Jika siswa tidak dapat 
memahami konsep perkalian bilangan bulat seperti perkalian bilangan negatif dengan bilangan negatif, bilangan positif dengan bilangan negatif, bilangan negatif dengan bilangan positif, bilangan positif dengan positif, dan sifat perkalian bilangan nol maka mereka tidak akan dapat menyelesaikan permasalahan perkalian bilangan bulat dengan tepat. Oleh karena itu, siswa perlu memahami konsep perkalian bilangan bulat dengan baik. Namun siswa masih mengalami kesulitan mengerjakan soal perkalian bilangan bulat. Berdasarkan hasil penelitiannya Utami (2016) dan Mulyati (2017) menjelaskan bahwa kondisi siswa masih mengalami kesulitan dalam menyelesaikan soal operasi hitung campuran pada bilangan bulat. Kesulitan yang dialami siswa adalah tidak memahami konsep sifat-sifat operasi perkalian dengan baik. Dalam buku Kaune, Christa \& Elmar CohorsFresenborg (2017) menjelaskan bahwa selain memahami konsep perkalian bilangan bulat dengan baik, siswa juga harus menghindari kesalahan sintaksis dan kesalahan semantik.

Kesalahan sintaksis merupakan kesalahan penulisan yang dilakukan oleh siswa atau suatu pelanggaran terhadap bentuk yang telah disepakati seperti penulisan kurung yang tidak lengkap atau kelebihan kurung. Sedangkan kesalahan semantik merupakan kesalahan perhitungan.

Kesalahan yang dilakukan oleh siswa dalam menyelesaikan soal perkalian bilangan bulat mungkin sama dengan yang dialami sekolah lainnya, termasuk di SMPK St. Paulus Karuni. Berdasarkan hasil wawancara yang peneliti lakukan dengan guru matematika kelas VII dan berdasarkan pengalaman mengajar di SMPK St. Paulus Karuni diperoleh bahwa perkalian bilangan bulat adalah salah satu materi yang cukup sulit bagi siswa yaitu tidak memahami konsep dengan baik dan tidak dapat menghitung dengan baik. Beberapa siswa melakukan kesalahan pada perkalian bilangan bulat. Oleh karena itu, peneliti tertarik untuk menganalisis sejumlah jenis kesalahan yang dilakukan siswa dalam menyelesaikan berbagai permasalahan mengenai perkalian bilangan bulat pada kelas VII. Peneliti memberikan soal tes kepada siswa kelas VII SMPK St. Paulus Karuni.
Tes yang diberikan kepada siswa berupa soal perkalian bilangan bulat. Tes ini tidak hanya meminta siswa memberikan hasilnya tetapi siswa harus mengerjakan melalui proses dengan langkah-perlangkah beserta memberikan alasan. Alasan-alasan tersebut berupa aksioma $\left(\mathrm{N}^{+}, \mathrm{N}^{\mathrm{x}}, \mathrm{I}^{+}\right.$, $\mathrm{I}^{\mathrm{X}}, \mathrm{K}^{+}, \mathrm{K}^{\mathrm{x}}, \mathrm{A}^{+}, \mathrm{A}^{\mathrm{x}}$, dan $\left.\mathrm{D}^{-}\right)$maupun teoremateorema (T1 - T17) yang sesuai dan yang telah mereka pelajari. Berikut aksioma dan teoremateorema yang digunakan adalah sebagai berikut:

\section{AKSIOMA DAN TEOREMA PADA}

\section{PENJUMLAHAN DAN PENGURANGAN}

\begin{tabular}{|l|l|}
\hline $\mathbf{N}^{+}$ & $(\mathbf{0}+\boldsymbol{a})=\boldsymbol{a}$ \\
\hline $\mathbf{I}^{+}$ & $(\boldsymbol{a}+(-\boldsymbol{a}))=\mathbf{0}$ \\
\hline $\mathbf{K}^{+}$ & $(\boldsymbol{a}+\boldsymbol{b})=(\boldsymbol{b}+\boldsymbol{a})$ \\
\hline $\mathbf{A}^{+}$ & $((\boldsymbol{a}+\boldsymbol{b})+\boldsymbol{c})=(\boldsymbol{a}+(\boldsymbol{b}+\boldsymbol{c}))$ \\
\hline $\mathbf{D}^{-}$ & $(\boldsymbol{a}-\boldsymbol{b})=(\boldsymbol{a}+(-\boldsymbol{b}))$ \\
\hline T1 & $(\boldsymbol{a}+\mathbf{0})=\boldsymbol{a}$ \\
\hline T2 & $\mathbf{0}=(-\mathbf{0})$ \\
\hline T3 & $(\mathbf{0}-\boldsymbol{a})=(-\boldsymbol{a})$ \\
\hline T4 & $(\boldsymbol{a}-\boldsymbol{a})=\mathbf{0}$ \\
\hline T5 & $(\boldsymbol{a}-\mathbf{0})=\boldsymbol{a}$ \\
\hline T6 & $(-(-\boldsymbol{a}))=\boldsymbol{a}$ \\
\hline T7 & $(\boldsymbol{a}-(-\boldsymbol{b}))=(\boldsymbol{a}+\boldsymbol{b})$ \\
\hline T8 & $((-\boldsymbol{a})-(-\boldsymbol{b}))=(\boldsymbol{b}-\boldsymbol{a})$ \\
\hline T9 & $(-(\boldsymbol{a}+\boldsymbol{b}))=((-\boldsymbol{a})+(-\boldsymbol{b}))$ \\
\hline T10 & $((-\boldsymbol{a})+\boldsymbol{b})=(-(\boldsymbol{a}-\boldsymbol{b}))$ \\
\hline T11 & $(-(\boldsymbol{a}-\boldsymbol{b}))=(\boldsymbol{b}-\boldsymbol{a})$ \\
\hline T12 & $((\boldsymbol{a}+\boldsymbol{b})-\boldsymbol{c})=(\boldsymbol{a}+(\boldsymbol{b}-\boldsymbol{c}))$ \\
\hline
\end{tabular}

AKSIOMA DAN TEOREMA PADA PERKALIAN BILANGAN BULAT

\begin{tabular}{|l|l|}
\hline $\mathbf{N}^{\mathbf{x}}$ & $(\mathbf{1} \times \boldsymbol{a})=\boldsymbol{a}$ \\
\hline $\mathbf{K}^{\mathbf{x}}$ & $(\boldsymbol{a} \times \boldsymbol{b})=(\boldsymbol{b} \times \boldsymbol{a})$ \\
\hline $\mathbf{A}^{\mathbf{x}}$ & $((\boldsymbol{a} \times \boldsymbol{b}) \times \boldsymbol{c})=(\boldsymbol{a} \times(\boldsymbol{b} \times \boldsymbol{c}))$ \\
\hline $\mathbf{D}$ & $(\boldsymbol{a} \times(\boldsymbol{b}+\boldsymbol{c}))=((\boldsymbol{a} \times \boldsymbol{b})+(\boldsymbol{a} \times \boldsymbol{c}))$ \\
\hline T13 & $(\mathbf{0} \times \boldsymbol{a})=\mathbf{0}$ \\
\hline T14 & $(\boldsymbol{a} \times(-\boldsymbol{b}))=(-(\boldsymbol{a} \times \boldsymbol{b}))$ \\
\hline T15 & $((-\boldsymbol{a}) \times \boldsymbol{b})=(-(\boldsymbol{a} \times \boldsymbol{b}))$ \\
\hline T16 & $((-\boldsymbol{a}) \times \boldsymbol{b})=(\boldsymbol{a} \times(-\boldsymbol{b}))$ \\
\hline T17 & $((-\boldsymbol{a}) \times(-\boldsymbol{b}))=(\boldsymbol{a} \times \boldsymbol{b})$ \\
\hline
\end{tabular}

Sumber: Kaune, Christa \& Elmar Cohors_Fresenborg (2017). 


\section{METODE}

Jenis penelitian yang digunakan dalam penelitian ini adalah penelitian kualitatif deskriptif. Penelitian ini bertujuan untuk mendeskripsikan jenis-jenis kesalahan siswa tentang perkalian bilangan bulat. Subjek penelitian ini adalah 18 siswa kelas VII tahun ajaran 2019/2020 yang terdiri atas 12 perempuan dan 6 laki-laki.

Prosedur penelitian ini terdiri dari 3 tahapan utama yaitu persiapan, implementasi, dan analisis data. Pada tahap persiapan, peneliti menyiapkan permasalahan tentang perkalian bilangan bulat. Pada tahap selanjutnya, peneliti memberikan permasalahan yang berkaitan dengan Perkalian Bilangan Bulat. Selanjutnya peneliti menganalisis jawaban siswa untuk mengetahui dan mendeskripsikan kesalahan yang dilakukan siswa.

Teknik analisis data yang digunakan menurut Miles \& Huberman dalam Gunawan (2014) yaitu (1) reduksi data (data reduction): pada bagian ini, peneliti melakukan reduksi data yaitu merangkum dan memilih hal-hal yang penting untuk dianalisis, (2) paparan data (data display): pada bagian ini, peneliti melakukan analisis data berdasarkan rumusan masalah, dan (3) penarikan kesimpulan dan verifikasi (conclusion drawing/verifying): pada bagian ini, peneliti menarik kesimpulan yang berkaitan dengan jenis-jenis kesalahan yang dilakukan siswa pada perkalian bilangan bulat.

\section{HASIL DAN PEMBAHASAN}

Peneliti memberikan tes perkalian bilangan bulat kepada siswa kelas VII yang berjumlah 18 orang. Berdasarkan hasil analisis data, peneliti menemukan 4 kesalahan yang dilakukan siswa ketika menyelesaikan permasalahan tentang Perkalian Bilangan Bulat. Seluruh tipe kesalahan yang dilakukan dan jumlah kesalahan yang dilakukan siswa dapat dilihat pada Tabel 1 .

Tabel 1. Tipe kesalahan yang dilakukan siswa

\begin{tabular}{|l|c|}
\hline \multicolumn{1}{|c|}{ Tipe Kesalahan } & $\begin{array}{c}\text { Jumlah Siswa } \\
\text { Yang Melakukan } \\
\text { Kesalahan }\end{array}$ \\
\hline $\begin{array}{l}\text { Kesalahan konsep } \\
\text { (pemberian alasan) }\end{array}$ & 7 orang \\
\hline $\begin{array}{l}\text { Kesalahan Sintaksis } \\
\text { (Kesalahan penulisan) }\end{array}$ & 18 orang \\
\hline
\end{tabular}

\begin{tabular}{|l|c|}
\hline $\begin{array}{l}\text { Kesalahan Semantik } \\
\text { (Kesalahan menghitung) }\end{array}$ & 12 orang \\
\hline $\begin{array}{l}\text { Kesalahan melihat tanda } \\
\text { operasi }\end{array}$ & 1 orang \\
\hline
\end{tabular}

\section{Kesalahan Konsep (Pemberian Alasan)}

Pada tipe kesalahan yang pertama yaitu mengenai kesalahan konsep atau siswa memberikan alasan yang tidak sesuai. Kemungkinan mengapa siswa melakukan kesalahan karena siswa tidak dapat memahami dengan baik sifat-sifat perkalian bilangan bulat yang terdapat pada kontrak maupun teorema pada perkalian bilangan bulat. Berikut bentuk kesalahan yang siswa dilakukan oleh siswa:

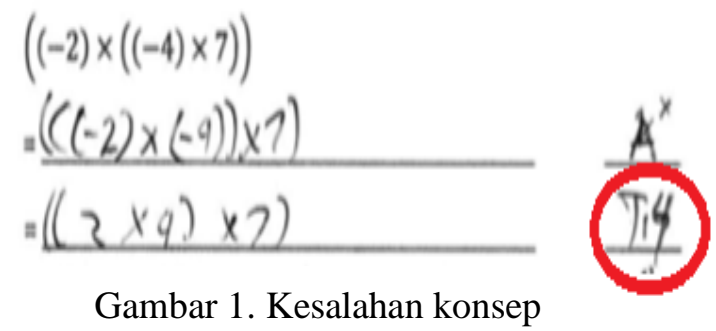

Pada gambar 1, terlihat bahwa siswa belum memahami alasan-alasan untuk operasi perkalian bilangan bulat sehingga siswa masih salah memberikan alasan yang sesuai dengan pengubahan pada baris ketiga. Pada baris yang ketiga siswa menggunakan T14 (teorema 14) yakni $(a \times(-b))=(-(a \times b))$ dan menuliskan pengubahannya $((-2) \times(-4))=$ $(2 \times 4)$. Alasan tersebut tidak sesuai dengan bentuk pengubahannya. Pada T14 yang negatif hanya di b sedangkan pada bentuk $((-2) \times$ $(-4))=(2 \times 4)$ yang negatif yaitu a dan $b$, maka alasan yang sesuai yaitu T17 dengan bentuk $((-a) \times(-b))=(a \times b)$.

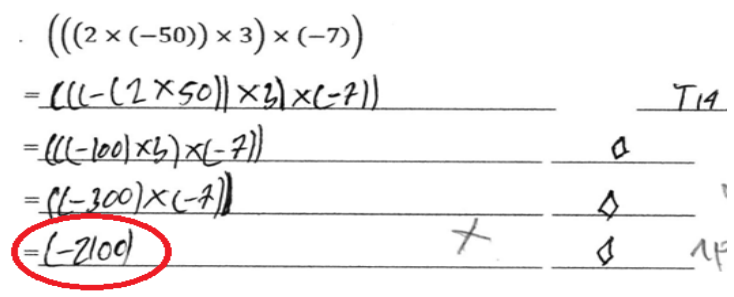

Gambar 2. Kesalahan konsep yang dilakukan siswa

Pada gambar 2, siswa diminta untuk menyelesaikan soal $(((2 \times(-50)) \times 3) \times$ $(-7))$ dengan menerapkan berbagai alasan yang sesuai. Pada pengubahan yang pertama baris kedua, siswa menggunakan T14 $(a \times(-b))=$ $(-(a \times b))$, untuk mengubah

$(2 \times$ 
$(-50))$ menjadi $(-(2 \times 50))$. Pada pengubahan yang kedua baris ketiga, siswa menggunakan Lupis $(\diamond)$ untuk menghitung $(2 \times 50)=100$. Selanjutnya pada baris yang keempat siswa menggunakan lupis $(\nabla)$ lagi untuk $((-100) \times 3)=(-300)$. Pada pengubahan ini siswa kurang menerapkan satu alasan, seharusnya siswa harus terlebih dahulu mengubah $((-100) \times 3)$ menjadi $(-(100 \times 3))$ dengan alasan $T 15((-a) \times b)=(-(a \times$ $b)$ ), kemudian terakhir menggunakan lupis $(\diamond)$. Pada baris yang terakhir siswa menggunakan alasan lupis untuk pengubahan $((-300) \times$ $(-7))=(-2100)$. Pada bagian ini, siswa melakukan kesalahan yaitu siswa tidak memahami dengan baik konsep sifa-sifat perkalian bilangan bulat seperti perkalian bilangan negatif dengan bilangan negatif. Seharusnya sebelum menggunakan alasan lupis $(\diamond)$, terlebih dahulu harus menggunakan alasan $T 17((-a) \times(-b))=(a \times b), \quad$ untuk mengubah $\quad((-300) \times(-7))$ menjadi $(300 \times 7), \quad$ kemudian terakhir menggunakan lupis $(\diamond)$ untuk menghitung $(300 \times 7)=2100$.

\section{Kesalahan Sintaksis (Kesalahan Penulisan).}

Kesalahan sintaksis merupakan kesalahan yang dilakukan oleh siswa pada bentuk penulisan matematika seperti terdapat kelebihan tanda kurung atau kurang tanda kurung. Kemungkinan mengapa siswa melakukan kesalahan sintaksis karena siswa tidak dapat melihat dan mengontrol sendiri (monitoring) jawabannya apakah masih ada kesalahan. Berikut bentuk kesalahan yang dilakukan oleh siswa:

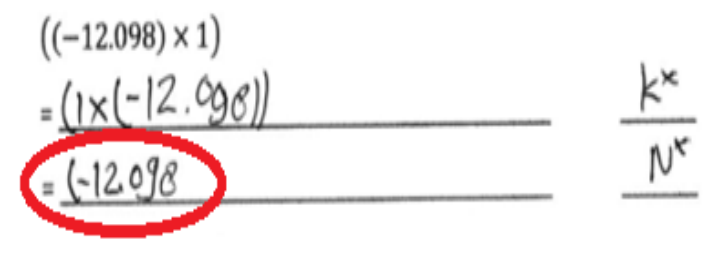

Gambar 3. Kesalahan sintaksis yang dilakukan oleh siswa

Pada gambar 3, siswa diminta untuk menghitung hasil dari $((-12.098) \times 1)$ dengan memberikan alasan-alasan yang sesuai. Pertama siswa menggunakan alasan $K^{\times}(a \times$ $b)=(b \times a)$ untuk pertukaran tempat antara $(-$
12.098) dengan 1, yang semula (-12.098) disebelah kiri dari tanda kali berpindah ke kanan dari tanda kali dan sama halnya juga dengan 1 yang semula berada disebelah kanan dari tanda kali berpindah disebelah kiri dari tanda kali. Kemudian pada baris selanjutnya siswa menggunakan alasan $\mathrm{N}^{\mathrm{x}}(1 \times a)=a$ dengan pengubahannya (-12.098. Pada pengubahannya di baris ketiga ini terjadi kesalahan sintaksis yaitu siswa tidak menuliskan kurung tutup. Seharusnya pengubahan yang terakhir menjadi (12.098).

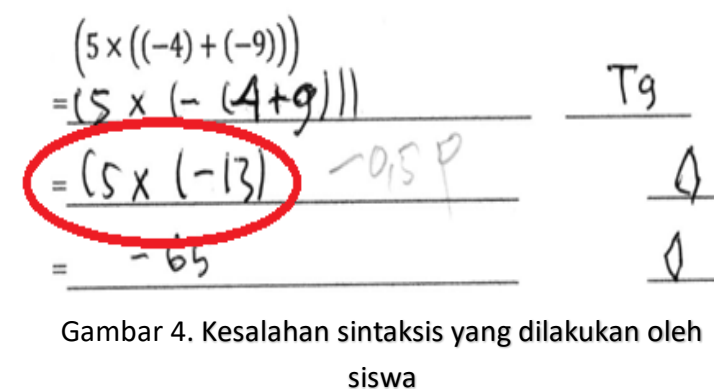

Pada gambar 4, siswa diminta untuk menghitung hasil dari $(5 \times((-4)+$ $(-9))$ ) dengan memberikan alasanalasan yang sesuai. Pertama siswa menggunaka $\mathrm{n}$ alasan $T 9$ (teorema 9) dengan pengubahan $((-4)+(-9)) \quad$ menjadi $(-(4+9))$ yang sebagai a yaitu 4 dan sebagai b yaitu 9 . Kemudian pada baris selanjutnya siswa menggunakan alasan Lupis $(\diamond)$ untuk menghitung $4+9=13$. Pada pengubahannya di baris ketiga ini yang telah diberi tanda lingkaran merah terjadi kesalahan sintaksis yaitu siswa tidak menuliskan kurung tutup. Siswa tidak memperhatikan bahwa kurung tutup yang terakhir merupakan pasangan kurungnya kurung buka pada sebelum - 13 . Seharusnya pengubahan pada baris yang ketiga yaitu $(5 \times(-13))$. Kemudian pada baris yang terakhir siswa menggunakan alasan lupis $(\nabla)$ untuk menghitung $(5 \times(-13))=-65$.

\section{Kesalahan semantik (Kesalahan menghitung)}

Kesalahan semantik merupakan kesalahan yang dilakukan oleh siswa pada saat perhitungan. Kemungkinan siswa melakukan kesalahan semantik karena siswa tidak dapat menghitung dengan baik dan tidak mengerti konsep perkalian dari SD dengan baik. Siswa hanya sistem menghafal saja tetapi tidak tahu dari mana itu berasal. Sebagai contoh siswa tahu 
kalau $3 \times 8=24$ tetapi siswa tidak memahami dari mana itu didapat. Berikut bentuk kesalahan yang dilakukan oleh siswa:

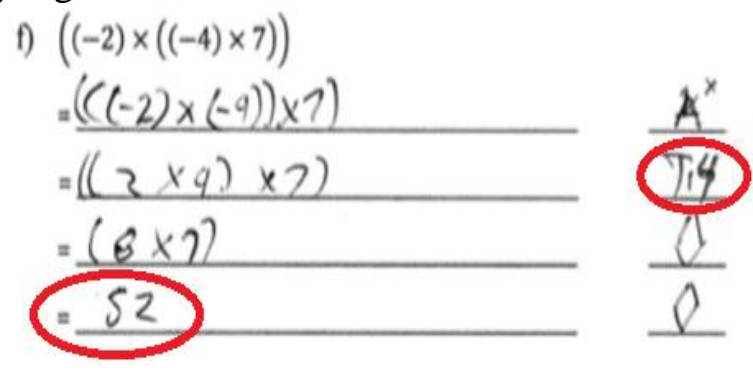

Gambar 5. Kesalahan semantik yang dilakukan siswa.

Pada latihan ini (gambar 5), siswa diminta untuk menyelesaikan $((-2) \times((-4) \times 7))$ dengan memberikan alasan-alasan yang sesuai. Pada baris yang kedua siswa menggunakan alasan $\mathrm{A}^{\mathrm{x}}$ untuk mengubah yang semula yang satu kelompok kecil yaitu (-4) dan 7 berubah menjadi yang satu kelompok yaitu (-2) dan (-4). Kemudian pada baris ketiga siswa melakukan kesalahan konsep yaitu menggunakan alasan T14 untuk pengubahan tersebut, seharusnya T17 yang sesuai. Kemudian pada baris keempat, siswa menggunakan alasan lupis $(\diamond)$ untuk pengubahan $(2 \times 4)=8$. Selanjutnya pada baris yang terakhir siswa menggunakan alasan lupis $(\nabla)$ untuk pengubahan $(8 \times 7)=52$. Pada baris ini siswa melakukan kesalahan semantik, seharusnya hasil dari $(8 \times 7)=56$.

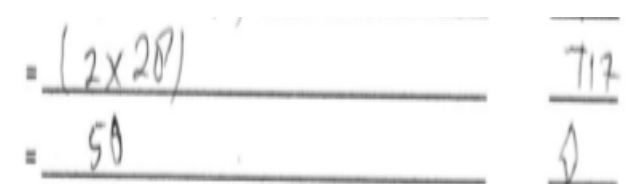

Gambar 6. Kesalahan semantik yang dilakukan siswa.

Pada gambar 6, terlihat bahwa siswa belum dapat berhitung dengan baik. Siswa salah dalam menghitung 2 dengan 28 dan hasilnya 50 . Siswa menggunakan alasan lupis $(\diamond)$ untuk menghitung $(2 \times 28)=50$. Seharusnya hasil kali 2 dengan 28 adalah 56.

\section{Kesalahan melihat tanda operasi.}

Selain kesalahan Konsep, kesalahan Sintaksis dan kesalahan semantik, siswa juga melakukan kesalahan seperti salah melihat tanda operasi. Contohnya mereka berpikir operasi tambah merupakan operasi kali. Kemungkinan pertama siswa melakukan kesalahan ini karena siswa tidak melihat dengan baik tanda yang ada pada soal. Sedangkan kemungkinan kedua karena siswa tidak memahami dengan baik mengenai tanda operasi misalkan tanda tambah (+) berfungsi untuk apa, tanda kali (x) berfungsi untuk apa. Berikut bentuk kesalahan yang dilakukan oleh siswa:

$((-2) \times(-550))$

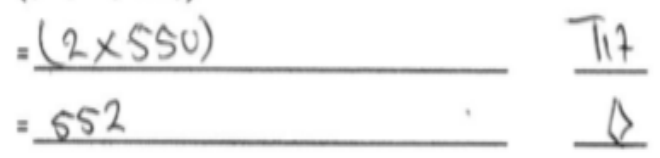

Gambar 7. Kesalahan melihat tanda operasi

Pada latihan di atas (gambar 7), siswa diminta untuk menyelesaikan soal $((-2) \times(-550))$ dengan memberikan alasanalasan yang sesuai. Pertama siswa menggunakan alasan T17 $((-a) \times(-b))=(a \times b)$, dengan mengubah $\quad((-2) \times(-550))$ menjadi $(2 \times 550)$ yang sebagai variabel a adalah 2 dan sebagai $b$ adalah 550, pengubahannya dari kiri ke kanan. Kemudian selanjutnya siswa menggunakan alasan lupis $(\nabla)$ untuk perhitungan $(2 \times 550)=552$. Terlihat bahwa siswa tidak memperhatikan dengan baik bahwa tanda operasinya bukan tanda tambah melainkan tanda kali. Sehingga siswa melakukan kesalahan yaitu menjumlahkan 2 dengan 550 dan siswa menjawab hasilnya adalah 552. Pada bagian ini, siswa tidak melihat dan mengontrol kembali apa yang sudah dikerjakan. Seharusnya pengubahannya dengan alasan lupis $(\diamond)$ yaitu $(2$ $\times 550)=1.100$.

\begin{tabular}{|c|c|}
\hline $\begin{aligned} & (5 \times((-4)+(-9))) \\
= & (5 \times(-(4 \times 9)))\end{aligned}$ & $\mathrm{Tg}$ \\
\hline$=(5 \times(-3))$ & $\Delta$ \\
\hline$=(-15 \times 3))$ & $T 14$ \\
\hline$=(-65)$ & $\Delta$ \\
\hline
\end{tabular}

Gambar 8. Kesalahan yang dilakukan siswa

Pada gambar 8, terlihat bahwa siswa melakukan kesalahan yang sama yaitu kesalahan yang berhubungan dengan tanda operasi. Pada baris kedua pengubahan yang pertama siswa menggunakan alasan $T 9(-(a+b))=$ $((-a)+(-b))$ untuk pengubahan $((-4)+$ $(-9))=(-(4 \times 9))$. Disini siswa melakukan kesalahan yaitu ia menulis tanda kali 
pada 4 dan 9 yang seharusnya pengubahannya $((-4)+(-9))=(-(4+9))$. Kemudian pada baris ketiga, siswa menggunakan alasan lupis $(\diamond)$ untuk menghitung $(4 \times 9)$ dan hasilnya siswa menjawab 3. Disini siswa melakukan kesalahan lagi siswa tidak dapat menghitung dengan tepat seharusnya $\quad(-(4 \times 9))=$ (-36). Kemudian pada baris selanjutnya pengubahan ketiga siswa menggunakan alasan $T 14(a \times(-b))=(-(a \times b)), \quad$ untuk pengubahan $\quad(5 \times(-3))=(-(5 \times 3))$. Kemudian pada baris terakhir, siswa melakukan kesalahan perhitungan dengan menggunakan alasan lupis $(\diamond)$ untuk perhitungan $(-(5 \times 3))=(-$ $65)$, seharusnya $(-(5 \times 3))=(-15)$.

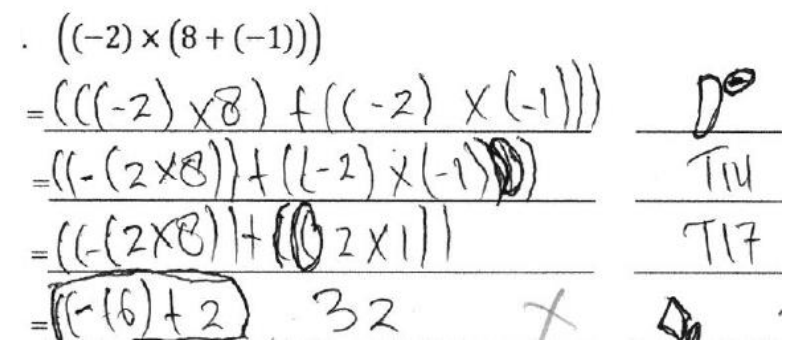

Gambar 9. Kesalahan melihat tanda operasi

Pada gambar 9, siswa diminta untuk menyelesaikan $((-2) \times(8+(-1)))$. Pada pengubahan baris pertama siswa menggunakan alasan D (distributif) dengan pengubahannya. Selanjutnya pada pengubahan baris ketiga siswa menggunakan alasan T14 untuk mengubah $((-2) \times 8)=(-(2 \times 8)) . \quad$ Pada baris selanjutnya siswa mengubah $((-2) \times(-1))=$ $(2 \times 1)$ dengan alasan T17. Selanjutnya pada baris yang terakhir, siswa menggunakan alasan lupis untuk mengubah $(((-2) \times 8)+(2 \times$ 1) $)=32$. Kita dapat melihat jawaban siswa yang diberi lingkaran disamping 32 , siswa tersebut menuliskan $((-16)+2)$. Sehingga dari bentuk tersebut dapat kita tahu bahwa siswa salah dalam mengartikan tanda operasi tambah menjadi tanda kali sehingga menjawab $((-16)+2)=32$. Namun siswa juga melakukan kesalahan jika menggunakan operasi perkalian bilangan bulat seharusnya menghasilkan (-32).

\section{KESIMPULAN}

Berdasarkan hasil penelitian dan pembahasan, diperoleh kesalahan yang dilakukan oleh siswa Kelas VII SMPK St. Paulus Karuni yaitu terdapat 4 tipe kesalahan dalam menyelesaikan permasalahan terkait materi perkalian bilangan bulat dengan berbagai kemungkinan alasan pada setiap kesalahan yang dianalisa. Seluruh kesalahan yang ditemukan dalam penelitian ini adalah kesalahan konsep, kesalahan sintaksis, kesalahan menghitung yang dilakukan oleh siswa (kesalahan semantik) dan kesalahan melihat tanda operasi. Kesalahan konsep terjadi karena siswa tidak memahami dengan baik konsep perkalian bilangan bulat, siswa hanya sistem menghafal bukan memahami sehingga terkadang terjadi kesalahan konsep yang dilakukan oleh siswa. Kesalahan sintaksis merupakan kesalahan yang dilakukan oleh siswa pada bentuk penulisan matematika seperti terdapat kelebihan tanda kurung atau kurang tanda kurung. Kesalahan sintaksis terjadi karena siswa tidak dapat melihat dan mengontrol sendiri (monitoring) jawabannya apakah masih ada kesalahan. Kesalahan semantik merupakan kesalahan yang dilakukan siswa pada saat perhitungan. Kemungkinan siswa melakukan kesalahan semantik karena siswa tidak dapat menghitung dengan baik dan tidak mengerti konsep perkalian dari SD dengan baik. Sedangkan kesalahan terakhir yang dilakukan oleh siswa yaitu salah dalam melihat tanda operasi seperti siswa menganggap bahwa tanda operasi tambah merupakan tanda perkalian sehingga seharusnya bilangan tersebut dijumlahkan tetapi siswa tersebut malah mengalikan bilangan tersebut dan begitupun sebaliknya.

\section{SARAN}

Saran menggambarkan hal-hal yang akan dilakukan terkait dengan gagasan selanjutnya dari penelitian tersebut. Hambatan-hambatan atau permasalahan yang dapat mempengaruhi hasil penelitian juga disajikan pada bagian ini.

\section{UCAPAN TERIMA KASIH}

Ucapan terima kasih terutama ditujukan kepada pemberi dana penelitian atau donatur. Ucapan terima kasih dapat juga disampaikan kepada 
pihak-pihak yang membantu pelaksanaan penelitian.

\section{DAFTAR PUSTAKA}

Ate, D. 2(016). Jumping Back And ForthPermainan Sebagai Microworld Untuk Memperkenalkan Konsep Bilangan Bulat. Yogyakarta : Seminar Nasional Matematika dan Pendidikan Matematika.

Departemen Pendidikan Nasional. 2008. Kamus Besar Bahasa Indonesia Pusat Bahasa. Jakarta : PT Gramedia Pustaka Utama.

Gatot Muhsetyo, dkk. 2015. Pembelajaran Matematika SD. Tangerang Selatan : Universitas Terbuka.

Gunawan, Iman. 2014. Metode Penelitian Kualittaif: Teori dan Praktik. Jakarta: Bumi Aksara.

Karlimah, Nur, L., \& Oktaviyani, H. 2019. Pemahaman Konsep Operasi Hitung Penjumlahan Bilangan Cacah Siswa Sekolah Dasar. Premiere Educandum: Jurnal Pendidikan Dasar dan Pembelajaran Volume 9 (2) 123-129.

Karso, dkk. 2011. Pendidikan Matematika 1. Jakarta : Universitas Terbuka

Kaune, Christa \& Elmar Cohors_Fresenborg. 2017. Kontrak untuk perhitungan, buku kerja untuk siswa kelas 7. STKIP Weetebula : Lembaga Matematika Kognitif.

Mulyati, Sri. 2017. Analisis kesalahan matematika dilihat dari motivasi belajar belajar siswa pada materi operasi hitung bilangan bulat kelas VII SMPN 17 Purworejo.Universitas Muhammadiyah Purworejo.

Notodiputro, Khairil Anwar. 2013. Kompetensi Dasar dan Kompetensi Inti Kurikulum 2013. Kementrian Pendidikan dan Kebudayaan.

Utami, Lina. 2016. Analisis kesulitan siswa SMP kelas VII dalam menyelesaikan soal operasi hitung bilangan dan solusi pemecahannya.Universitas Muhammadiyah Surakarta 